\title{
Media Herbarium Book Meningkatkan Kreativitas Anak Usia Dini
}

\section{Ida Ayu Kade Ari Widiastuti1*, I Wayan Widiana², Dewa Gede Firstia Wirabrata ${ }^{3}$}

1,2,3 Jurusan Pendidikan Guru Pendidikan Anak Usia Dini, STKIP Modern, Ngawi, Indonesia

\section{A R T I C L E I N F O}

Article history:

Received 27 April 2021

Revised 28 April 2021

Accepted 01 Juli 2021

Available online 25 Agustus 2021

Kata Kunci:

Kreativitas, Media, Herbarium Book

Keywords:

Creativity, Media, Herbarium Book

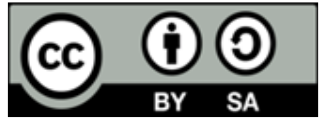

This is an open access article under the CC BY-SA license.

Copyright (@) 2021 by Author. Published by Universitas Pendidikan Ganesha.

\begin{abstract}
A B S T R A K
Permasalahan yang terjadi saat ini yaitu masih banyak anak yang memiliki kreativitas yang kurang. Guru kurang kreatif dalam menggunakan media pembelajaran sehingga anak kurang berminat dalam mengembangkan kreativitas dalam mengerjakan tugas yang diberikan oleh guru. Penelitian ini bertujuan untuk menciptakan media herbarium book yang dapat meningkatkan kreativitas anak. Jenis penelitian ini adalah penelitian pengembangan dengan menggunakan prosedur ADDIE. Subjek dalam penelitian ini berjumlah 2 orang ahli materi pembelajaran, dan 2 orang ahli media pembelajaran. Teknik yang digunakan dalam mengumpulkan data yaitu observasi, wawancara, dan kuesioner. Instrument yang digunakan dalam mengumpulkan data yaitu kuesioner. Teknik yang digunakan dalam menganalisis data yaitu analisis kualitatif dan kuantitatif. Hasil penelitian ini yaitu penilaian dari ahli materi pembelajaran mendapatkan nilai 4 dan penilaian ahli media pembelajaran mendapatkan nilai 3,68 sehingga media herbarium book mendapatkan kategori sangat tinggi. Jadi media yang dikembangkan layak diterapkan dalam proses pembelajaran. Implikasi penelitian ini yaitu media herbarium book yang dikembangkan dapat meningkatkan semangat dan kreativitas pada anak usia dini.
\end{abstract}

\begin{abstract}
A B S T R A C T
The problem that occurs today is that there are still many children who have less creativity. Teachers are less creative in using learning media so that children are less interested in developing creativity in doing the tasks given by the teacher. This study aims to create a herbarium book media that can increase children's creativity. This type of research is development research using the ADDIE procedure. The subjects in this study amounted to 2 learning material experts, and 2 learning media experts. The techniques used in collecting data are observation, interviews, and questionnaires. The instrument used in collecting data is a questionnaire. The technique used in analyzing the data is qualitative and quantitative analysis. The results of this study are the assessment of the learning material experts getting a value of 4 and the assessment of the learning media experts getting a value of 3.68 so that the herbarium book media gets a very high category. So the media developed is feasible to be applied in the learning process. The implication of this research is that the developed herbarium book media can increase enthusiasm and creativity in early childhood.
\end{abstract}

\section{PENDAHULUAN}

Kreativitas adalah kemampuan berpikir dalam menciptakan ataupun menghasilkan sesuatu yang baru dan berbeda yang belum ada sebelumnya (Prahesti et al., 2020). Kreativitas biasanya akan muncul pada seseorang yang memiliki imajinasi, rasa ingin tahu serta motivasi yang tinggi. Seseorang yang kreatif akan mencari serta menemukan jawaban untuk memecahkan masalah, serta memiliki sikap terbuka pada hal baru (bersikap fleksibel), dapat mengekspresikan diri, memiliki sikap natural. Kreativitas juga akan berpengaruh pada aspek perkembangan kognitif anak (Nurani \& Mayangasri, 2017). Hal ini menyebabkan anak menjadi lebih aktif dan kreatif dalam mengerjakan kegiatan yang berhubungan dengan kognitif. Kemampuan kognitif anak yang berkembang baik akan mempengaruhi kreativitas anak pula (Bunce, 2021; Saggar et al., 2019). Karakteristik ciri individu kreatif yaitu memiliki inisiatif, imajinatif, memiliki minat, mandiri dalam berpikir, rasa ingin tahu yang tinggi, jiwa petualangan, penuh semangat, berani, percaya diri, dan berdani dalam berpendapat serta keyakinan (Oztop \& Gummerum, 2020; Piotrowski \& 
Meester, 2018). Secara natural sesungguhnya akan dapat mempelajari sesuatu dengan caranya sendiri. Sifat natural mendasar ini yang seharusnya dikembangkan oleh guru sehingga kreativitas pada anak usia dini tidak hilang (Katimo et al., 2016; Roca \& Ford, 2021; Wandi \& Mayar, 2019).

Hanya saja permasalahan yang terjadi saat ini yaitu masih banyak anak yang memiliki kreativitas yang kurang (Mardliyah et al., 2021; Marwiyati \& Istiningsih, 2021). Permasalahan ini juga ditemukan di TK Negeri Tukadmungga. Berdasarkan hasil observasi dan wawancara ditemukan bahwa kreativitas anak belum berkembang. Dilihat dari keseharian anak dalam proses pembelajaran, anak masih sangat kurang berani dan kurang percaya diri dalam mengambil resiko dalam mengerjakan tugas yang diberikan oleh guru. Kurangnya kreativitas anak dalam menciptakan karya baru, kurang berani dalam berpendapat dan belum yakin dalam mengeluarkan kemampuan yang dimiliki, menyebabkan kemampuan yang dimiliki anak belum terasah dengan baik. Hal tersebut dapat dilihat pada saat kegiatan pembelajaran yang dilakukan pada PAUD ini masih terlihat kurang bervariasi dan kurang menarik. Guru hanya menggunakan model pembelajaran yang berpusat pada guru sehingga anak cenderung pasif. Selain itu, kurangnya media pembelajaran yang menarik juga membuat siswa kesulitan dalam memahami dan mencerna informasi yang disampaikan oleh guru saat pembelajaran berlangsung. Guru kurang kreatif dalam menggunakan dan memafaatkan media pembelajaran contohnya media pembelajaran yang ada kurang mampu meningkatkan kreativitas anak sehingga anak kurang berminat dalam mengembangkan kreativitas dalam mengerjakan tugas yang diberikan oleh guru. Selain itu, anak masih kesulitan mengungkapkan idenya sehingga anak masih membutuhkan waktu lama, dan adanya masa pandemi seperti sekarang ini proses belajar mengajar kini menjadi sangat sulit. Hal ini dikarenakan guru tidak dapat melihat anak belajar secara langsung di rumah. Sementara untuk pelaksanaan pembelajaran diperankan atau dilakukan oleh orang tua dirumah masing-masing peserta didik tetap menggunakan prinsip bermain sambil belajar (Yulianto \& Nugraheni, 2021). Hal inilah yang menyebabkan anak menjadi tidak percaya diri untuk menjawab ataupun mengerjakan tugas yang diberikan oleh guru dalam mendorong kreativitas anak (Lilawati, 2020).

Dalam upaya meningkatkan kreativitas anak usia dini maka diperlukan media pembelajaran yang menarik. Salah satu media pembelajaran yang dapat dimanfaatkan yaitu media Herbarium Book. Herbarium merupakan koleksi spesimen yang telah dikeringkan dan diawetan dan dapat disusun berdasarkan sistem klasifikasi (Dikrullah et al., 2018; Ranti \& Hazizah, 2016). Herbarium kering adalah koleksi spesimen yang telah dikeringkan, dan dapat ditempel pada kertas (mounting paper), diberi label berisi keterangan. Media ini dapat diawetkan serta disimpan dengan baik di tempat penyimpanan yang kering. Herbarium ini adalah jenis tumbuhan kering yang telah melewati tahap proses pengawetan. Media Herbarium book yang akan dikembangkan dapat ditempelkan pada buku yang telah berisikan keterangan dari tumbungan yang digunakan. Media ini akan menjadi kegiatan yang sangat menyenangkan bagi anak karena menggunakan bagian taaman yang unik sehingga anak tertarik dan antusias mengikuti pembelajaran (Susilo, 2015). Kegiatan pembelajaran dilaksanakan melalui proses bermain sehingga anak akan termotivasi dalam belajar. Kegiatan belajar sambil bermain adalah pembelajaran yang sangat disukai oleh anak usia dini (Perdina et al., 2019; Swastrini et al., 2016). Agar herbarium ini dapat digunakan dengan mudah maka pengembangan media herbarium ini dibuat menjadi buku dalam bentuk Herbarium book.

Beberapa penelitian sebelumnya yang berkaitan dengan penggunaan media herbarium book menyebutkan bahwa media herbarium book dapat membantu proses belajar anak usia dini sehingga anak-anak mampu memahami materi pembelajaran dengan baik (Asra et al., 2019). Penelitian lainnya juga menyebutkan bahwa media herbarium book mampu meningkatkan aktifitas belajar siswa, sehingga semua siswa dapat ikut berperan aktif dalam kegiatan pembelajaran (Nisaa et al., 2019). Penelitian relevan ketiga juga menyebutkan bahwa media Herbarium dapat membuat siswa termotivasi dalam belajar, sehingga proses pembelajaran dapat berjalan dengan maksimal. (Batubara, 2017).

Berdasarkan beberapa hasil penelitian terdahulu dapat dikatakan bahwa media herbarium book merupakan media yang cocok digunakan pada pembelajaran anak usia dini karena mampu meningkatkan semangat serta motivasi belajar anak. Hanya saja pada penelitian sebelumnya belum terdapat kajian mengenai Herbarium book yang dapat meningkatkan kreativitas pada anak usia dini. Sehingga penelitian ini difokuskan pada pengembahangan media herbarium book untuk meningkatkan kreatifitas siswa. Adapun tujuan penelitian ini yaitu untuk mencipatakan media pembelajaran berupa Herbarium book yang dapat digunakan oleh anak usia dini dalam belajar. 


\section{METODE}

Penelitian ini merupakan jenis penelitian pengembangan (Research and Development). Prosedur penelitian ini menggunakan model ADDIE yang meliputi lima tahapan, yaitu analysis, design, development, implementation, dan evaluating (evaluasi) (Tegeh \& Kirna, 2010). Adapun prosedur pengembangan tersaji pada gambar 1.

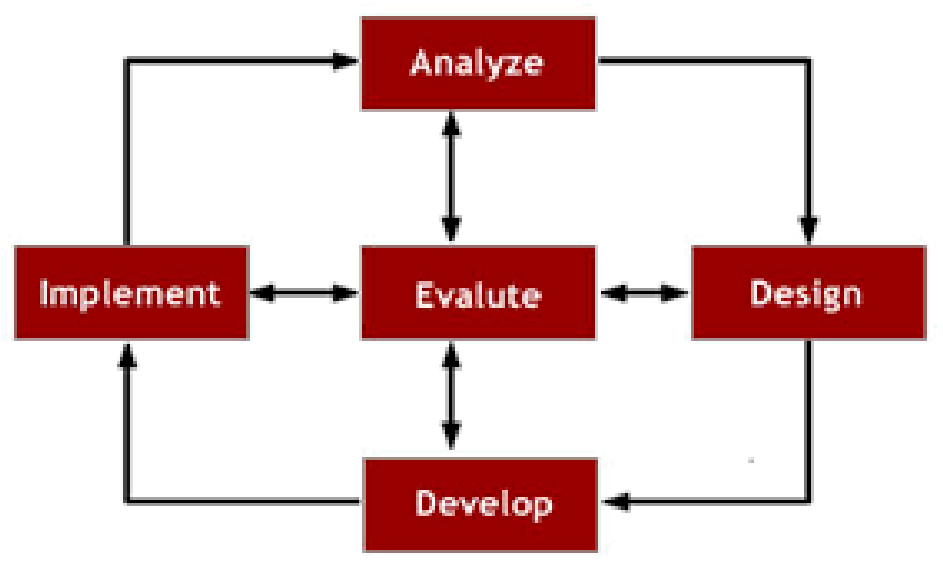

Gambar 1. Desain Penelitian Model ADDIE (Tegeh \& Kirna, 2010)

Subjek penelitian yang dikaji dalam penelitian ini adalah media Herbarium Book untuk meningkatkan kreativitas anak pada Kelompok B5 TK Negeri Desa Tukadmungga. Objek dalam penelitian ini adalah merupakan 2 orang ahli media pembelajaran, dan 2 orang ahli materi pelajaran. Metode pengumpulan data menggunakan observasi, wawancara, dan kuesioner. Observasi dan wawancara digunakan untuk mendapatkan informasi mengenai permasalahan yang ada. Kuesioner digunakan untuk mengumpulkan data tentang kelayakan penggunaan media Herbarium Book yang diberikan kepada para ahli. Instrument yang digunakan dalam mengumpulkan data yaitu kuesioner. Kisi-kisi kuesioner tersaji pada tabel 1 dan tabel 2 .

Tabel 1. Kisi-Kisi Instrumen Ahli Materi

\begin{tabular}{clll}
\hline No & \multicolumn{1}{c}{ Instrumen } & \multicolumn{1}{c}{ Indikator } \\
\hline 1. & Tujuan & 1. & Media Herbarium Book untuk mendukung dalam \\
& & & meningkatkan kreativitas anak \\
2. & Isi materi & 2. & Judul sesuai dengan isi materi \\
& & 3. & Isi media Herbarium Book meningkatkan kreativitas anak \\
& & 4. & Keruntutan Herbarium sesuai yang ada pada media \\
& & & Herbarium Book \\
3. & Kejelasan materi & 5. & Kejelasan pada media Herbarium Book \\
4. & Motivasi & 6. & Materi dapat memotivasi belajar anak \\
5. & Hasil Belajar & 7. & Kualitas hasil belajar anak akan jauh lebih baik karena \\
& & &
\end{tabular}

Tabel 2. Kisi-Kisi Instrumen Ahli Media Pembelajaran

\begin{tabular}{|c|c|c|}
\hline No & Instrumen & Indikator Penilaian \\
\hline \multirow[t]{4}{*}{1} & Estetika & 1. Kemenarikan media Herbarium Book \\
\hline & & $\begin{array}{l}\text { 2. Kesesuaian tumbuh-tumbuhan yang digunakan pada } \\
\text { media Herbarium Book }\end{array}$ \\
\hline & & 3. Kemenarikan Herbarium \\
\hline & & 4. Kesesuaian jenis ukuran Herbarium \\
\hline \multirow[t]{4}{*}{2} & Teknis & 5. Dapat digunakan dalam jangka waktu panjang \\
\hline & & 6. Kemudahan penggunaan produk Herbarium Book \\
\hline & & 7. Keawetan dengan baik \\
\hline & & 8. Kemenarikan kemasan produk \\
\hline
\end{tabular}

(Utomo et al., 2018) 
Untuk menguji validitas kontruksi dapat menggunakannya dari ahli penjurian (judgment expart). Mengukur validitas ini menggunakan rumus Gregory. Analisis yang digunakan dalam penelitian ini digunakan Analisis statistik kualitatif dan statistik kuantitatif. Digunakannya analisis statistik kualitatif data yaitu berupa tanggapan, kritik, dan saran dalam hasil review pakar ahli meliputi dua orang yaitu dosen dan kepala sekolah. Hasil dari tinjauan review ahli dianalisi dengan mengelompokkan data kualitatif dalam bentuk komentar dan saran yang digunakan untuk memperbaiki media yang dikembangkan. Analisis statistik kuantitatif digunakan mendeskripsikan dan menjelaskan skor rata-rata masing-masing ahli tentang media yang dikembangkan. Skor yang didapat kemudian dirata-rata untuk menentukan keefektifan (validitas) media Herbarium Book menggunakan rumus mean. Jumlah rata-rata skor yang telah diperoleh selanjutnya dikonversikan menggunakan pedoman skala empat.

\section{HASIL DAN PEMBAHASAN}

Hasil

Pengembangan media Herbarium Book dilaksanakan menggunakan model ADDIE dengan melalui beberapa tahap yakni: analisis, perancangan, pengembangan, implementasi, dan evaluasi. Namun ada tahapan yang tidak dapat terlaksana yaitu implementasi dan evaluasi. Hal ini dikarenakan keterbatasan waktu, tenaga, sumber daya, dan finansial. Pertama, tahap analisis (analyze). Tahap analisis ditempuh melalui beberapa tahapan yaitu analisis kebutuhan, analisis karakteristik siswa, analisis pembelajaran, dan analisis media. Hasil analisis kebutuhan yaitu anak masih sangat kurang berani dan kurang percaya diri dalam mengambil resiko dalam mengerjakan tugas yang diberikan oleh guru, kurangnya kreativitas anak dalam menciptakan karya baru, anak juga kurang berani dalam berpendapat dan belum yakin dalam mengeluarkan kemampuan yang dimiliki oleh anak, sehingga kemampuan yang dimiliki anak belum terasah dengan baik sehingga belum mendapatkan hasil yang optimal. Hasil analisis pembelajaran yaitu diperlukan media yang dapat mencapai tujuan dari pembelajaran itu sendiri dan tercapainya kompetensi dasar yang harus dicapai oleh anak. Analisis pembelajaran juga menganalisis KD, KI, indikator pada buku guru terkait pembelajaran Kreativitas pada anak. Hasil analisis media yaitu beberapa kriteria yang dilakukan diantaranya penentuan ukuran kertas karton dan kertas manila digunakan sebagai buku, kecocokan antara materi dengan indikator, tata letak antara tumbuh-tumbuhan dengan buku Herbarium, penggunaan dan kemudahan kata yang dipilih, melakukan pemilihan tumbuh-tumbuhan untuk pembuatan Herbarium.

Tahap kedua, perencanaan (design). Tahap ini memiliki tujuan untuk merancang media berdasarkan analisis yang telah dilakukan sebelumnya. Desain Pembuatan media yaitu dengan menentukan tumbuh-tumbuhan yang akan di pakai dalam pembuatan Herbarium. Pada tahap ini tumbuhtumbuhan yang dipakai dalam pembuatan Herbarium ini adalah menggunakan seperti tumbuhan endong, daun nangka, daun waru, daun kunyit, kembang sepatu. Setelah mengumpulkan tumbuh-tumbuhan yang akan dipakai ke dalam pembuatan Herbarium Book, kemudian potong kertas karton dan kertas manila dan di jalin menggunakan benang tri angel menjadi seperti buku, selanjutnya memotong kertas koran yang akan nantinya dipakai untuk mengeringkan tumbuhan yang dipakai Herbarium. Selanjutnya menyiapkan koran dan tisu kering untuk membumgkus tumbuh-tumbuhan yang nantinya akan dipakai sebagai Herbarium. Setelah kering buatkan pola Herbarium g sesuai kreativitas ke dalam kreasi yang akan dipakai dalam pembuatan buku Herbarium. Tempel tumbuh-tumbuhan tersebut ke dalam kertas manila kemudian tempel ke dalam buku karton yang akan nantinya sebagai buku Herbarium. Rancangan media Herbarium Book dapat pad dilihat pada Gambar 2. Tahap ketiga, pengembangan (development). Pada tahap pengembangan mulai dibuat media yang akan dikembangkan. Pada tahap ini dilaksanakan pengembangan media sesuai dengan rancangan yang sudah dibuat. Berikut ini tampilan media Herbarium Book yang sudah dikembangkan dapat dilihat pada Gambar 3. Setelah media Herbarium book dikembangkan, maka tahap selanjutnya yaitu uji media yang dilakukan oleh ahli materi pembelajaran dan media pembelajaran. Hal ini dilakukan untuk mengetahui kelayakan media Herbarium book yang telah dikembangkan. Berdasarkan hasil analisis uji media yang dilakukan oleh ahli materi pelajaran mendapatkan nilai 4 sehingga termasuk dalam kategori sangat tinggi. Hasil uji ahli media pembelajaran juga mendapatkan nilai 3,68 sehingga termasuk dalam kategori sangat tinggi. Berdasarkan penilaian tersebut maka media Herbarium book tidak perlu melakukan revisi. 


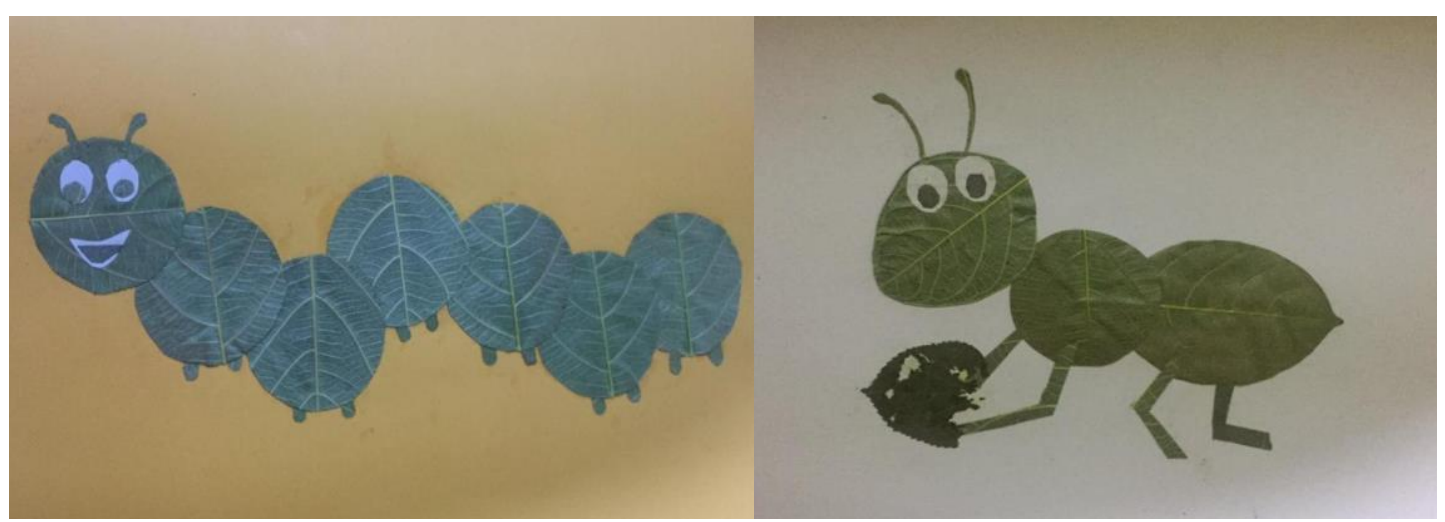

Gambar 2. Rancangan Media Herbarium Book

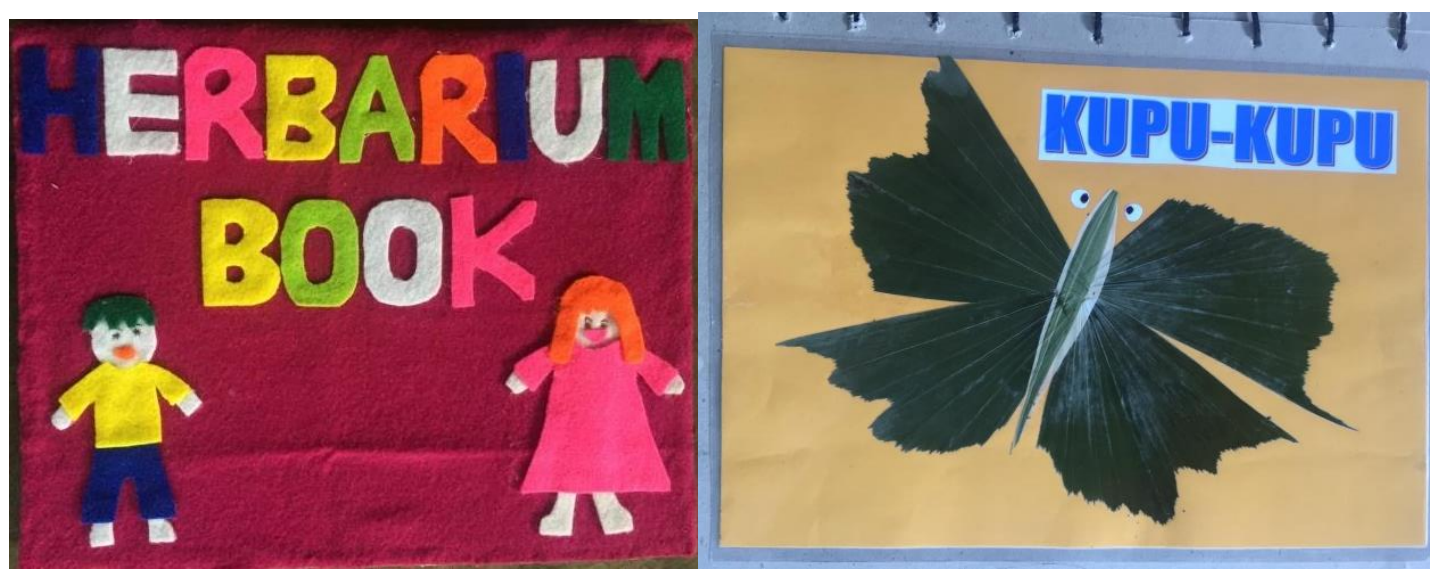

Gambar 3. Media Herbarium Book

\section{Pembahasan}

Berdasarkan analisis hasil penelitian dapat dikatakan bahwa media herbarium book yang dikembangkan berada dalam ketegori baik, hal ini disebabkan oleh beberapa faktor yaitu sebagai berikut: Pertama, media Herbarium book layak diterapkan dalam proses pembelajaran dapat membuat siswa termotivasi dalam belajar. Media Herbarium book menarik perhatian siswa dan membuat siswa termotivasi dalam belajar. Media pembelajaran yang menarik dan sesuai dengan perkembangan anak dapat meningkatkan motivasi belajar siswa (Chang et al., 2020; Heo \& Toomey, 2020). Tumbuhan yang digunakan dalam pembuatan Herbarium ini yaitu tumbuhan endong, daun nangka, daun waru, daun kunyit, kembang sepatu, sehingga akan mengenalkan jenis-jenis tumbuhan pada anak. Media pembelajaran yang memperkenalkan hal baru pada anak juga akan membangkitkan rasa keingintahuan siswa dalam belajar (Annisa et al., 2020; Delfia \& Mayar, 2020; Khan \& Masood, 2015). Bentuk ilustrasi yang disajikan pada media ini juga menarik sehingga memotivasi siswa dalam belajar. Penggunaan gambar dalam belajar akan meningkatkan semangat siswa (Aprinawati, 2017; Fatmasari et al., 2019; Handayani \& Abadi, 2020). Dalam kegiatan pembelajaran ini terlibat secara aktif. Hal ini disebabkan karena siswa sepenuhnya diberikan kebebasan untuk menempelkan herbarium kedalam buku. Tempel tumbuh-tumbuhan tersebut ke dalam kertas manila yang berwarna warni. Hal ini bertujuan untuk anak dapat mengenal warna dan anak dapat membedakan suatu benda mati ataupun benda hidup. Media yang menarik dan memberikan banyak informasi sehingga meningkatkan motivasi belajar siswa layak digunakan dalam proses pembelajaran (Gunawan et al., 2017; Priani et al., 2019).

Kedua, media Herbarium book layak diterapkan dalam proses pembelajaran dapat meningkatkan pemahaman dan kreativitas siswa. Dalam mengembangkan media ini disesuaikan dengan karakteristik materi dan siswa sehingga memudahkan siswa dalam memahami materi pembelajaran. Karakteristik anak usia dini adalah memiliki rasa antusias dan ingin tahu yang kuat terhadap banyak hal di sekitarnya (Fadlullah, 2017; Manurung et al., 2021; Mardliyah et al., 2020). Pada media Herbarium book menyajikan contoh nyata yang ada disekitar anak sehingga anak memiliki rasa antusias yang tinggi. Selain itu, media ini menggunakan jenis tumbuhan Herbarium ini yaitu sehingga dapat meningkatkan pemahaman siswa mengenai jenis-jenis tumbuhan. Dalam proses penyusunan anak juga diberikan kebebasan dalam menyusunnya tanpa harus mengikuti pola yang sudah ada sehingga akan meningkatkan kreativitas anak. 
Media pembelajaran yang baik akan membantu meningkatkan pemahaman siswa dalam belajar (Aulia \& Budiningsih, 2021; Kurnia et al., 2015; Manurung et al., 2021). Media pembelajaran juga akan meningkatkan kreativitas siswa jika siswa terlibat penuh dalam penggunaan media tersebut (Astuti \& Istiarini, 2020; Sari et al., 2020; Yusnia, 2019). Manfaat penggunaan herbarium ini yaitu dapat membantu guru dalam menjelaskan materi pelajaran, memberikan pemahaman pada anak mengenai pengawetan dan pengeringan tumbuhan, memberikan pengetahuan agar tetap meelestarikan tumbuhan disekitar anak, memacu anak menjadi inovatif dan kreatif (Dikrullah et al., 2018).

Hasil yang diperoleh dalam penelitian ini sejalan dengan hasil penelitian terdahulu yang juga menyatakan bahwa media herbarium book dapat membantu proses belajar anak usia dini sehingga anakanak mampu memahami materi pembelajaran dengan baik (Asra et al., 2019). Penelitian lainnya juga menyebutkan bahwa media herbarium book mampu meningkatkan aktifitas belajar siswa, sehingga semua siswa dapat ikut berperan aktif dalam kegiatan pembelajaran (Nisaa et al., 2019). Penelitian relevan ketiga juga menyebutkan bahwa media Herbarium dapat membuat siswa termotivasi dalam belajar, sehingga proses pembelajaran dapat berjalan dengan maksimal. (Batubara, 2017). Berdasarkan hasl tersebut dapat dikatakan bahwa media herbarium book layak untuk digunakan dalam kegiatan belajar anak usia dini. Kelebihan media herbarium book yaitu dapat digunakan secara praktis dan menunjukkan contoh konkrit terkait materi yang diajarkan sehingga meningkatkan pemahaman dan kreativitas anak. Adapun Implikasi penelitian ini yaitu media Herbarium Book yang telah dikembangkan Penggunaan media ini, dapat membantu guru dalam menyampaikan materi serta dapat membantu siswa dalam menerima dan memahami kegiatan pembelajaran dengan lebih mudah.

\section{SIMPULAN}

Berdasarkan hasil analisis data dan pembahasan dapat disimpulkan bahwa media Herbarium Book layak diterapkan dalam proses pembelajaran karena dapat meningkatkan pemahaman dan kreativitas pada anak usia dini. Hal ini dapat dilihat dari hari analisis uji validitas yang memperoleh hasil sangat baik.

\section{DAFTAR RUJUKAN}

Annisa, E. N., Supriyati, Y., \& Nurani, Y. (2020). Peningkatan Pemahaman Berhitung dan Kardinalitas melalui Penggunaan Media Rangkasbitung. Jurnal Obsesi : Jurnal Pendidikan Anak Usia Dini, 4(2). https://doi.org/10.31004/obsesi.v4i2.441.

Aprinawati, I. (2017). Penggunaan Media Gambar Seri Untuk Meningkatkan Kemampuan Berbicara Anak Usia Dini. Jurnal Obsesi: Jurnal Pendidikan Anak Usia Dini, 1(1), 72. https://doi.org/10.31004/obsesi.v1i1.33.

Asra, R., Johari, A., \& Haryadi, B. (2019). Pemanfaatan Media Herbarium untuk Meningkatkan Hasil Belajar Siswa di Pondok Pesantren Al Hidayah. Jurnal Karya Abdi Masyarakat, 3(1). https://doi.org/10.22437/jkam.v3i1.7008.

Astuti, \& Istiarini. (2020). Upaya Meningkatkan Kemampuan Membaca Permulaan Anak Usia 5-6 Tahun Melalui Media Puzzle di PAUD Flamboyan Sukasari Kota Tangerang. Ceria: Jurnal Program Studi Pendidikan Anak Usia Dini, 8(2). https://doi.org/10.31000/ceria.v11i2.2338.

Aulia, B. N. R., \& Budiningsih, C. A. (2021). Tingkat Pemahaman Guru Taman Kanak-kanak di Lombok dalam Stimulasi Pengembangan Bahasa Anak Usia Dini. Jurnal Obsesi : Jurnal Pendidikan Anak Usia Dini, 5(1). https://doi.org/10.31004/obsesi.v5i2.1082.

Batubara, H. H. (2017). Pengembangan Media Pembelajaran Matematika berbasis Android untuk Siswa SD/MI. Urnal Madrasah Ibtidaiyah, 4(1), 9-15. https://doi.org/10.31602/muallimuna.v3i1.952.

Bunce, L. (2021). Fantasy orientation and creativity in childhood: A closer look. Jacqueline D. Woolley, 57. https://doi.org/10.1016/j.cogdev.2020.100979.

Chang, T. Y., Hong, G., Paganelli, C., Phantumvanit, P., Chang, W. J., Shieh, Y. S., \& Hsu, M. L. (2020). Innovation of dental education during COVID-19 pandemic. Journal of Dental Sciences, 1(155). https://doi.org/10.1016/j.jds.2020.07.011.

Delfia, E., \& Mayar, F. (2020). Analisis Pembelajaran Berhitung melalui Media Prisma Pintar pada Anak Usia Dini. Jurnal Obsesi: Journal of Early Childhood Education, 4(1). https://doi.org/10.31004/obsesi.v4i1.350.

Dikrullah, D., Rapi, M., \& Jamilah, J. (2018). Pengembangan Herbarium Book Sebagai Media Pembelajaran Biologi Pada Mata Kuliah Struktur Tumbuhan Tinggi. Jurnal Biotek, 6(1). https://doi.org/https://doi.org/10.24252/jb.v6i1.4426.

Fadlullah. (2017). Pendidikan Anak Usia Dini dalam Perspektif Islam. Jurnal Pendidkan Islam, 6(2). 
https://doi.org/10.29313/tjpi.v6i2.3195.

Fatmasari, D., Purba, A., \& Salikun, S. (2019). Media Permainan Tebak Gambar Efektif Dalam Peningkatan Pengetahuan Dan Tindakan Menyikat Gigi Dibandingkan Media Booklet. Jurnal Kesehatan Gigi, 6(1). https://doi.org/10.31983/jkg.v6i1.4447.

Gunawan, G., Sahidu, H., Harjono, A., \& Suranti, N. M. Y. (2017). The effect of project based learning with virtual media assistance on student's creativity in physics. Jurnal Cakrawala Pendidikan, 1(2). https://doi.org/10.21831/cp.v36i2.13514.

Handayani, R., \& Abadi, I. B. G. S. (2020). Pengaruh Model Pembelajaran Langsung Berbantuan Media Gambar Terhadap Kompetensi Pengetahuan Matematika Siswa Kelas IV SD. Mimbar Ilmu Undiksha, 25(1), 120-131. https://doi.org/10.23887/mi.v25i1.24767.

Heo, M., \& Toomey, N. (2020). Learning with multimedia: The effects of gender, type of multimedia learning resources, and spatial ability. Computers and Education, 146, 103747. https://doi.org/10.1016/j.compedu.2019.103747.

Katimo, Suparmi, \& Sukarmin. (2016). Pengaruh Pembelajaran dengan Pendekatan Saintifik Menggunakan Metode Eksperimen dan Demonstrasi terhadap Prestasi dan Kreativitas Ditinjau dari Sikap Ilmiah. Inkuiri: Jurnal Pendidikan IPA, 5(2). https://doi.org/10.20961/inkuiri.v5i2.9482.

Khan, F. M. A., \& Masood, M. (2015). The Effectiveness of an Interactive Multimedia Courseware with Cooperative Mastery Approach in Enhancing Higher Order Thinking Skills in Learning Cellular Respiration. Procedia - Social and Behavioral Sciences, 176, 977-984. https://doi.org/10.1016/j.sbspro.2015.01.567.

Kurnia, D., Taufiq, M., \& Silawati, E. (2015). Analisis Capaian Perkembangan Bahasa Anak Usia Dini Dalam Kegiatan Pembelajaran Dengan Metode Learning Based Resources. Cakrawala Dini: Jurnal Pendidikan Anak Usia Dini, 6(2). https://doi.org/10.17509/cd.v6i2.10520.

Lilawati, A. (2020). Peran Orang Tua dalam Mendukung Kegiatan Pembelajaran di Rumah pada Masa Pandemi. Jurnal Obsesi: Jurnal Pendidikan Anak Usia Dini, 5(1), 549. https://doi.org/10.31004/obsesi.v5i1.630.

Manurung, A. K. R., Wulan, S., \& Purwanto, A. (2021). Permainan Outdoor dalam Membentuk Kemampuan Ketahanmalangan pada Anak Usia Dini. Jurnal Pendidikan Anak Usia Dini, 5(2), 1807-1814. https://doi.org/10.31004/obsesi.v5i2.1030.

Mardliyah, S., Siahaan, H., \& Budirahayu, T. (2020). Pengembangan Literasi Dini melalui Kerjasama Keluarga dan Sekolah di Taman Anak Sanggar Anak Alam Yogyakarta. Jurnal Obsesi : Jurnal Pendidikan Anak Usia Dini, 4(2). https://doi.org/10.31004/obsesi.v4i2.476.

Mardliyah, S., Yulianingsih, W., \& Putri, L. S. R. (2021). Sekolah Keluarga: Menciptakan Lingkungan Sosial untuk Membangun Empati dan Kreativitas Anak Usia Dini. Jurnal Obsesi : Jurnal Pendidikan Anak Usia Dini, 5(1). https://doi.org/10.31004/obsesi.v5i1.665.

Marwiyati, S., \& Istiningsih, I. (2021). Pembelajaran Saintifik pada Anak Usia Dini dalam Pengembangan Kreativitas di Taman Kanak-Kanak. Jurnal Obsesi: Jurnal Pendidikan Anak Usia Dini, 5(1). https://doi.org/10.31004/obsesi.v5i1.508.

Nisaa, R. A., Lestari, S., \& Astuti, Y. (2019). Pelatihan Pembuatan Herbarium Sebagai Salah Satu Pengembangan Media Pembelajaran Biologi Berbasis Lingkungan Di Sma Muhammadiyah 1 Dan 2 Tangerang. Jurnal Pengabdian Masyarakat Dan Pendidikan MIPA, 3(1).

Nurani, Y., \& Mayangasri, T. (2017). Pengembangan Model Kegiatan Sentra Bermain Dalam Mengembangkan Kreativitas Anak Usia Dini. Jurnal Pendidikan Usia Dini, 11(2). https://doi.org/10.21009/JPUD.112.15.

Oztop, P., \& Gummerum, M. (2020). Group creativity in children and adolescents. Cognitive Development, 56. https://doi.org/10.1016/j.cogdev.2020.100923.

Perdina, S., Safrina, R., \& Sumadi, T. (2019). Peningkatan Kemampuan Sosial melalui Bermain Kartu Estafet pada Anak Usia Dini. Jurnal Obsesi: Jurnal Pendidikan Anak Usia Dini, 3(2). https://doi.org/10.31004/obsesi.v3i2.222.

Piotrowski, J. T., \& Meester, L. (2018). Can apps support creativity in middle childhood? Computers in Human Behavior, 85. https://doi.org/10.1016/j.chb.2018.03.030.

Prahesti, wantyka I., Taulany, H., \& Dewi, N. K. (2020). Gerak dan Lagu Neurokinestetik (GELATIK) untuk Menumbuhkan Kreativitas Seni Anak Usia Dini. Jurnal Obsesi : Jurnal Pendidikan Anak Usia Dini, 4(1). https://doi.org/10.31004/obsesi.v4i1.289.

Priani, I., Manuaba, I. B. S., \& Darsana, I. W. (2019). Pengaruh Model Problem Based Learning (PBL) Berbantuan Media Gambar Terhadap Hasil Belajar IPA Siswa Kelas V Gugus III Kuta Utara Tahun Pelajaran 2017/2018. Mimbar PGSD, 7(1). https://doi.org/10.23887/jjpgsd.v7i1.16972.

Ranti, E. S., \& Hazizah, N. (2016). Pengaruh Kegiatan Herbarium Terhadap Perkembangan Kreativitas Anak di PAUD Kasih Ibu I Luar Parit. Jurnal PG-Paud Trunojoyo, 6(1). 
https://doi.org/10.21107/pgpaudtrunojoyo.v6i1.5372.

Roca, A., \& Ford, P. R. (2021). Developmental activities in the acquisition of creativity in soccer players. Thinking Skills and Creativity, 41. https://doi.org/10.1016/j.tsc.2021.100850.

Saggar, M., Xie, H., Beaty, R. E., Stankov, A. D., Schreier, M., \& Reiss, A. L. (2019). Creativity slumps and bumps: Examining the neurobehavioral basis of creativity development during middle childhood. NeuroImage, 69(3). https://doi.org/10.1016/j.neuroimage.2019.03.080.

Sari, N. M., Yetti, E., \& Hapidin. (2020). Pengembangan Media Permainan Mipon's Daily untuk Meningkatkan Kemampuan Berhitung Anak. Jurnal Obsesi : Jurnal Pendidikan Anak Usia Dini, 4(2), 831. https://doi.org/10.31004/obsesi.v4i2.428.

Susilo, J. (2015). Analisis Kualitas Media Pembelajaran Insektarium dan Herbarium untuk Mata Pelajaran Biologi Sekolah Menengah. Jurnal Bioedukatika, https://doi.org/10.26555/bioedukatika.v3i1.4141.

Swastrini, Antara, P. A., \& Tirtayani, L. A. (2016). Penerapan Bermain Ular Tangga Untuk Meningkatkan Kemampuan Kerjasama Kelompok B1 di TK Widya Sesana Sangsit. Pendidikan Anak Usia Dini, 4(2). https://doi.org/10.23887/paud.v4i2.7764.

Tegeh, I. M., \& Kirna, I. M. (2010). Metode Penelitian Pengembangan Pendidikan. Undiksha.

Utomo, I. A., Ramli, M., \& Furaidah, F. (2018). Penerapan Strategi Bermain melalui Media Busy Book untuk Meningkatkan Fisik Motorik Halus Anak Usia Dini. Jurnal Pendidikan: Teori, Penelitian, Dan Pengembangan, 3(12). https://doi.org/10.17977/jptpp.v3i12.12553.

Wandi, Z. N., \& Mayar, F. (2019). Analisis Kemampuan Motorik Halus dan Kreativitas pada Anak Usia Dini melalui Kegiatan Kolase. Jurnal Obsesi: Jurnal Pendidikan Anak Usia Dini, 4(1), 363. https://doi.org/10.31004/obsesi.v4i1.347.

Yulianto, D., \& Nugraheni, A. S. (2021). Efektivitas Pembelajaran Daring Dalam Pembelajaran Bahasa Indonesia. Decode: Jurnal Pendidikan Teknologi Informasi, 1(1), 33-42. https://doi.org/10.51454/decode.v1i1.5.

Yusnia, Y. (2019). Penggunaan Media Video Scribe Dalam Pembelajaran Literasi Sains Untuk Mahasiswa PGPAUD. Cakrawala Dini: Jurnal Pendidikan Anak Usia Dini, 10(1), 71-75. https://doi.org/10.17509/cd.v10i1.17436. 